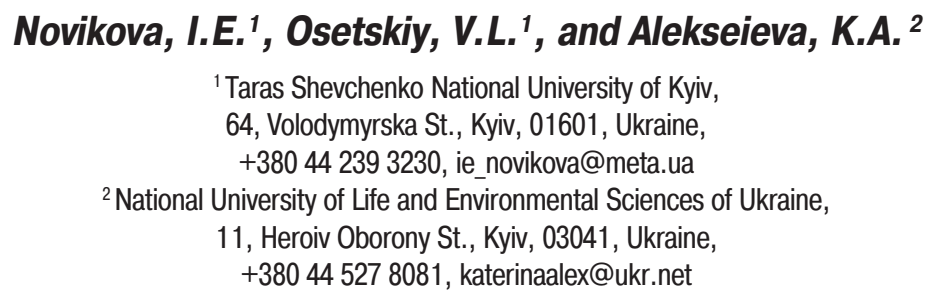

\title{
STARTUPS AND SPINOFFS AS FACTORS OF THE ACADEMIC BUSINESS DEVELOPMENT: THE FOREIGN EXPERIENCE AND THE UKRAINIAN PROSPECTS
}

\begin{abstract}
Introduction. Modern, equipped with cutting-edge technologies universities are a perfect environment for creating the primary atmosphere of innovative business climate.

Problem Statement. The implementation of modern, profitable innovation projects (startups or spinoffs) in the form of small innovative enterprises is a new way of successful commercialization of promising ideas. Universities are perfect site for launching the first startup ideas.

Purpose. To study the trends of academic business development in the context of increasing importance of innovation activities, in particular, the role of startups and spinoffs in the activities of foreign and Ukrainian universities.

Materials and Methods. There has been used the comparison of world universities ratings. The SWOT-analysis of the prospects of startup and spinoff projects has been carried out based on the universities of Ukraine. Analysis of dependence of the proceeds from innovative achievements on the costs of R\&D works has been made.

Results. A comparative overview of the trends in the development of academic business abroad and in Ukraine has been made. The national and European legislation in the sphere of formation of R\&D products has been analyzed. The factors that sufficiently hamper the development of innovative process in Ukraine have been identified. Recommendations concerning popularizing the innovative and investment activities and establishing fruitful international cooperation have been given.

Conclusions. The obtained results enable formulating the principles for the formation of a new methodological paradigm for intellectual assets management in universities taking into account the peculiarities of the development of national science, economy, entrepreneurship, and high-tech market.
\end{abstract}

Keywords: innovative business, commercialization of innovations, intellectual assets, intellectual property, startup, spinoff, Universities, and academic capitalism.

\section{INTRODUCTION}

Nowadays, the development of economic structures is frequently accompanied with turbulent transformation processes at micro- and macro levels, in particular, social and economic shocks and geopolitical challenges. That is why the attention of researchers and managers has been attracted to creating effective directions of eco-

(C) NOVIKOVA, I.E., OSETSKIY, V.L., and ALEKSEIEVA, K.A., 2018 nomic growth. In this connection, the necessity of essential increase in the innovative component among the factors of economic evolution has become crucial. However, in Ukraine, the real conditions and trends are hidden under the lack of correspondence between the science and innovation genesis and the world practice. For example, the national hi-tech market has only started its formation and consequently can be characterized as the one with a low quantity of innovation projects and companies. In this context, the key role 
in the national economy development should be given to small business, i.e. startups that are able to show positive dynamics through some new markets occupation with the help of new products, technologies, and business models invention. In its turn, this will create the opportunities for diversification of the economy technological basis. A perfect environment for forming the initial atmosphere for innovative business climate should be universities equipped with state-of-theart technologies. The priority assignment is to create a productive system of cooperation between the science and the entrepreneurs through intensifying the process of implementation of the most commercially attractive ideas into the civil circulation as well as the simultaneous preparation of highly qualified staff for this aim.

The aim of this research is in the considering the trends of development of academic business in the context of the strengthening the importance of innovative activities in particular defining of the role of start-ups and spin-offs in the foreign and Ukrainian Universities activities.

\section{THE ANALYSIS OF SCHOLARLY RESEARCH STUDIES AND PUBLICATIONS}

The problems connected with the development of innovative business at universities have been more or less studied in the works of both foreign (H. Etzkowitz [1], B. Clark [2], B. Serbinovski [3], J. Röpke [4], F. Yansen [5] etc.) and Ukrainian researchers (O. Zhylinska [6], O. Romanovskyi [7], I. Tatomyr [8] etc.). However, despite the existing trend of raising quantity of scholarly research works on the mentioned problem discussions, still go on both in Ukraine and abroad.

\section{THE MAIN RESULTS OF RESEARCH}

Nowadays, the entrepreneurial activity is considered to be the main force of the efficient economy. To provide the evolution and prosperity in the current conditions of modern highly competitive economic climate, the entrepreneurs try to be armed with innovative vehicles and experience. In this connection, it has become a priori- ty in many countries to stimulate people to be involved in creativity, innovations, and entrepreneurship. The ways of effective combination of science, education, business, and government has also become very relevant, in particular, in the context of the necessity to implement modern profitable innovative projects in the forms of small innovative enterprises.

Today, many Ukrainian businessmen and governors have heard the words "startup" or "spinoff", but for the majority of them they are just new words despite the fact that there are Wikipedia, Instagram or YouTube among the most popular startups. We also deal with various technological applications and reconstructions of artworks in everyday life. Because of the fact that all these projects have appeared to be very profitable, the place of startups in modern economy has become very important. For example, the markets of Europe, Asia, and America are getting more and more engaged in technological parks, scientific parks and innovative and investment funds (ventures and business incubators). All these structures promote risky projects to the market in order to reach the aim of capitalization of their income.

In Ukraine, new trends at the political, scientific, and business levels, have been vividly described in some preliminary studies. However, the work has just started and is very complicated in its institutional and legislative aspects. Frequently, this is caused by the lack of juridical definitions of these innovation notions in the Ukrainian legislation [9].

In the business environment, the term "startup" or "startup company" is understood as a promising profitable company or a project with a short story of its activity. As a rule, the startups are absolutely new projects, very often, at the stage of their elaboration. The most successful startups are ITprojects and internet-projects. However, such projects can take place in other promising branches - medical, chemical, etc. Some technologies of fuel combustion intensification or pure water offers can be considered startups, as well. 
It is necessary to admit that the startups can be temporary structures existing only at the time of searching for some business model. The existence of startups is always connected with uncertainty and risks. That is why the startups can be compared to trailblazers or explorers of new unknown territories. High risks of failure can be partly compensated by expected profits for entrepreneurs. Their strategy often called "the explorer strategy" by the strategic management experts is a radical transformation of the current market conditions for the implementation of innovative projects and their commercialization. The countries with developed conditions for existence and development of startups outrun the countries where the conditions are not created. As for the social development, it cannot be forgotten that small business is the activity where the person can utilize his/her potential. Small business can be easily considered the main factor that underlies the middle class formation and the main condition for social prosperity of the country.

The countries that have succeeded in the creation of conditions for the small business development, in particular, the startups, can be considered as those that have worked out mechanisms for the economic and social development.

Among the options for successful implementation of economically promising ideas there are spinoffs, i.e. the goods produced as byproduct/ accompanying goods to the main products. They can be actively promoted to the market together with the products that have been well-known to the customers. Such measures can enable getting even more commercial profits (for ex., auto chemistry at machinery manufacture).

The most famous spinoffs in the modern business are literature and cinematograph works, computer games and comics with the main characters that used to appear in other works and have become very popular among the audience. For example, The Scorpion King, a spin of The Mummy Returns and series of The X-Men (Wolverine and the X-Men, Wolverine 2. Immortal, and Wol- verine 3: Logan), etc. The most famous spinoffs are technological works of NASA that used to be applied for the needs of space industry, including a new system of water filtering, digital sensor imaging and water cleaning.

In the modern world, a perfect site for implementing the startup ideas is university. At the classical higher education establishment, there are all needed conditions, the structural departments, i.e. the centers for technology transfer, which can help to overcome all institutional barriers on the way to the international markets. In addition, ambitious young innovators have an exclusive opportunity to obtain substantial assistance from alma-mater: advise, training, resources, legislative support, etc. The modern universities accumulate knowledge, scientific achievements, up-to-date equipment, and funds, which can support financially the prospecting innovation products and technologies creation. Popularization and widening of innovation business, especially among students, is very important given the fact that the youth is the most sustainable to possible failures and the majority of the young audience is not overloaded with routine problems because they have got not married or given birth to children and have no financial obligations. That is why according to the Global Entrepreneurship Monitor Report, the young businessmen are the main group, with 165 million being between 18 and 25 years old [11].

The intellectual property is an instrument that enables to successfully transfer technologies to the outside world for their further use by interested companies and customers. The opportunity of getting the property rights, the right to use and to dispose of the intellectual assets, stimulates the talented people, i.e. the creators of commercially attractive ideas, to shift to new sphere, in particular, to the sphere of innovative business. The innovative business development now is a global trend. The commercially advanced European and American universities are investing large money to provide an increase in the innovative business in long-term prospects. 


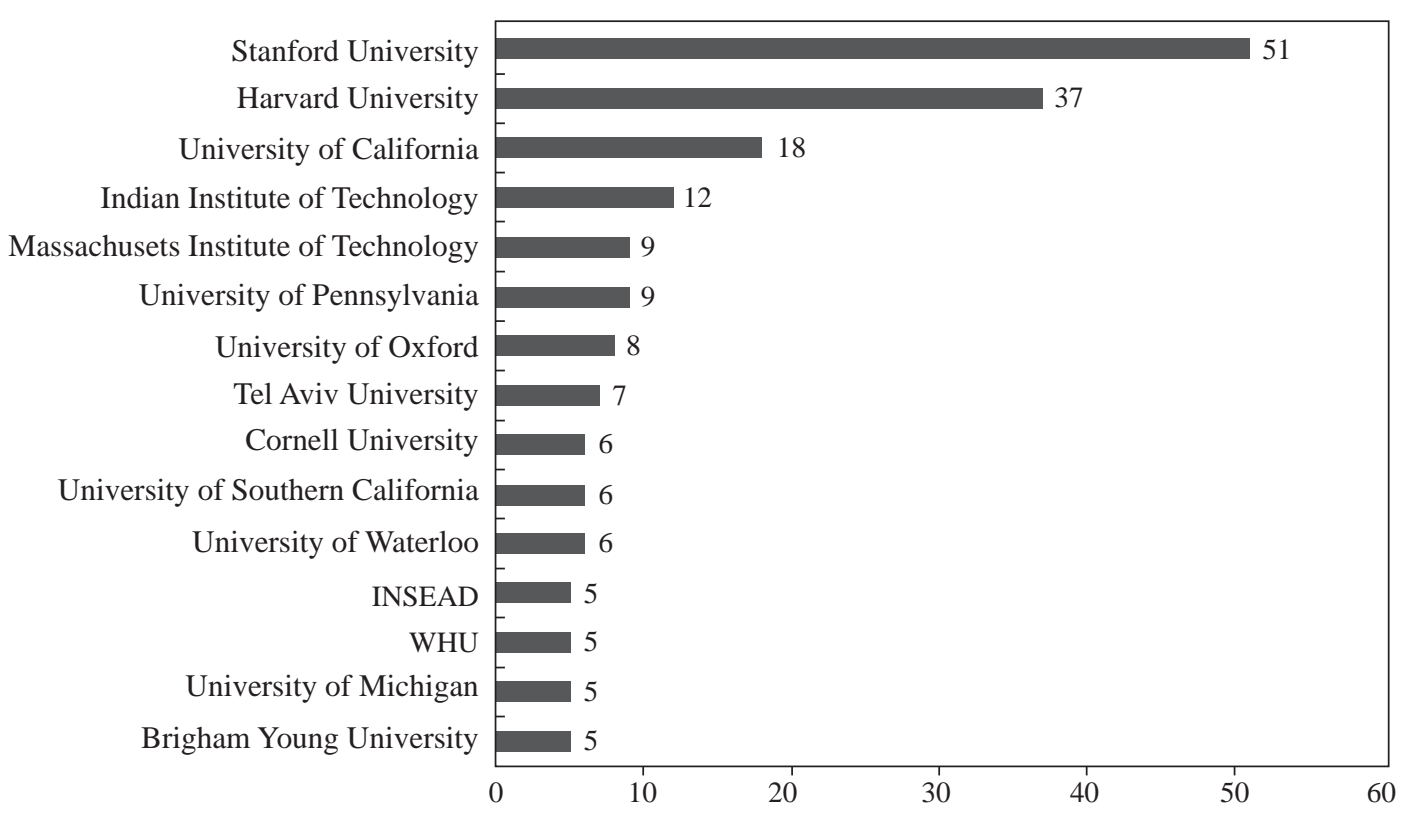

Fig. 1. Top 15 world universities with incorporated startups having a value over USD 1 billion Source: [13].

For instance, only the Oxford University invested 1 billion dollars into innovative startups, in 2017 [12]. This University has become a European leader and the founder of the biggest world companies such as LinkedIn, Funding Circle, and Eventbrite. However, the top places of the world ratings belong to the American Universities (Fig. 1, [13]) with more than 50 powerful innovative companies and Harvard (37 companies).

In this regard, at the beginning of 2017, according to recommendations of the European Commission, thanks to its support, a new promising project, Startup Europe Universities Network (SEUN), was launched in Euro zone [14]. The project aims at creating associations among universities and business/scholarly research structures for the development of innovative entrepreneurship due to the active mutual work on information sharing and practical support of promising projects. Also, the SEUN's work is to raise information about the technical entrepreneurship, to deeper understand trends, to share new ideas, initiatives on reforms, and advanced expe- rience, and to create the synergetic opportunities of cooperation.

Nowadays, the business innovations have become widely spread not only in the European countries and the USA, but also in the Africa and Asia countries, especially, in the economies showing a vivid economic growth at the beginning of the 21st century. By the way, the innovative culture is being successfully implemented both at the public higher educational establishments and at the private ones. One of these countries is Malaysia where the economic growth has proved to be among the highest ones in Asia within last several centuries. In this country, science is regulated by the Ministry of Science, Technologies, and Innovations in order to successfully combine the efforts of researchers, teachers, and entrepreneurs. In 1997, in Malaysia, University Tun Abdul Razak (UNIRAZAK), a private university, was established. This University was among the pioneers, with activities considered to be imperative for the future development of not only Malaysia, but of the whole Asian region. This University is positioned now as advanced establishment both 
in the sphere of educational services and in the field of human knowledge capitalization [15].

Recently, it has become a center of advanced experience implementation within the framework of intensifying and raising the human capital value. In this regard, the University permanently works on improving the quality of teaching and scholarly research. The main aim of the University is supporting the implementation of innovative achievements into the managerial and entrepreneurial economic activities. The University also does its best in the development of new creative knowledge including the managerial and entrepreneurial ones, in particular, due to startups. They actively stimulate cooperation on the mutual innovative and technological projects based on alliances with strategic partners. The productive innovative transformations in Malaysia have resulted in a tangible growth in the exports of hi-tech goods (for comparison: USD 10 bil- lion, in 1992 (26 years ago) versus USD 57 billion, in 2015. As for China, it has shown even more substantial development and overdone the USA, with its high-tech exports growing from USD 4 billion, in 1992, to USD 216 billion, in 2005. Since that period, China has not only been a leader in the world hi-tech exports, but also has become the world center insofar as its hi-tech exports are three times higher than that of the second ranked Germany (Table 1).

Estimating the innovative effectiveness based on the innovation costs we obtain the Global Innovation Index showing that the first place belongs to Switzerland, in 2016. Ukraine is only the 56th, but as compared with 2013 when it took the 71st place it has upward dynamics [16].

The task of forming the innovative-type economy with the help of existing intellectual and $\mathrm{R} \& \mathrm{D}$ capital is becoming more and more crucial for Ukraine. On January 1, 2015, new law On

The Comparative Analysis of Dependence of R\&D Costs and the Proceeds

Table 1 from Innovative Achievements of Some World Countries and Ukraine

\begin{tabular}{|c|c|c|c|c|}
\hline Countries & $\begin{array}{l}\text { Innovation Index } \\
(0-100) / \text { place } \\
\text { in rating } *\end{array}$ & $\begin{array}{l}\text { Costs for } \mathrm{R} \& \mathrm{D}, \% \\
\text { GDP / place } \\
\text { in rating ** }\end{array}$ & $\begin{array}{l}\text { Hi-tech exports, } \\
\text { USD million/ place } \\
\text { in rating } * * *\end{array}$ & $\begin{array}{c}\text { Share of business offering } \\
\text { innovative goods, \% / place } \\
\text { in rating * }\end{array}$ \\
\hline Switzerland & $67.7 / 1$ & - & $55906.71 / 11$ & $24.93 / 33$ \\
\hline Sweden & $63.8 / 2$ & $3.26 / 4$ & $16555.75 / 23$ & $29.5 / 18$ \\
\hline USA & $61.4 / 4$ & $2.79 / 9$ & $155640.59 / 3$ & $35.93 / 9$ \\
\hline Singapore & $58.7 / 7$ & $2.20 / 13(2014)$ & $137369.12 / 4$ & $20.47 / 49(2014)$ \\
\hline Finland & $58.5 / 8$ & $2.9 / 7$ & $3961.74 / 28$ & $29.4 / 22(2016)$ \\
\hline Germany & $58.4 / 9$ & $2.88 / 8$ & $199718.16 / 2$ & $23.74 / 35$ \\
\hline South Korea & $57.7 / 11$ & $4.23 / 2$ & $133447.40 / 5$ & $26.35 / 26$ \\
\hline Luxembourg & $56.4 / 12$ & $1.29 / 23$ & $642.36 / 57$ & $57.13 / 1$ \\
\hline Japan & $54.7 / 14$ & $3.28 / 3$ & $100954.83 / 7$ & $24.68 / 34$ \\
\hline Israel & $53.9 / 17$ & $4.27 / 1$ & $10241.48 / 27$ & $26.7 / 24$ \\
\hline China & $52.5 / 22$ & $2.07 / 14$ & $558605.99 / 1$ & $25.51 / 29$ \\
\hline Malaysia & $42.7 / 37$ & $1.3 / 22$ & $63376.04 / 10$ & $29.33 / 15$ \\
\hline Poland & $40.2 / 38$ & $1 / 29$ & $14487.25 / 25$ & $12.08 / 51$ \\
\hline Russian Federation & $38.8 / 45$ & $1.13 / 27$ & $9842.67 / 28$ & $5.4 / 64(2016)$ \\
\hline Ukraine & $37.6 / 50$ & $0.62 / 42$ & $1922.00 / 41$ & - \\
\hline Lebanon & $30.6 / 81$ & - & $38.15 / 85$ & $46.91 / 4$ \\
\hline
\end{tabular}

* Data of 2017, ** Data of 2015, *** Data of 2014.

Source: composed based on [11], [16], and [17]. 


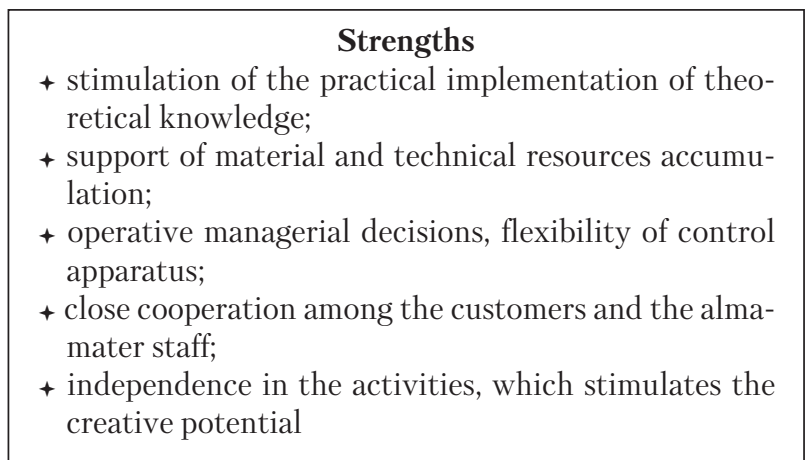

\section{Opportunities}

+ multivectoruniversities support: consultative, resource, legislative brand etc.;

+ easier market entrance;

+ tax privileges;

+ easier and faster reaction to changes;

+ highly qualified staff involvement;

+ involvement of the students through studying new ideas, entrepreneurial skills and their talent development;

+ creation of new academic culture;

+ super profit-making

\begin{tabular}{|l|} 
Weakness \\
+ ratherunstable structure in the case of different fluc- \\
tuations of market conditions and a high corruption; \\
+ lack of professional managers experienced in com- \\
mercialization of innovations, risk assessment, const- \\
ructionof different marketing strategies and business- \\
planning; \\
+ production of innovative goods is a costly business; \\
+ problems of production diversification; \\
+ highly risky activities
\end{tabular}

\section{Threats}

+ lack of required quantity ofinnovative projects;

+ problems in the legislative protection of intellectual property;

+ corruption, absence of the intellectual property right;

+ institutional barriers inthe sphere of project financing; limited access to credit resources;

+ problems in estimating and forecasting demand for innovative products;

+ political, social, and economic instability

Fig. 2. SWOT-analysis of prospects of university-basedstartups and spinoffs Source: [8].

Education came into force. Pursuant to this law, the universities are granted with new rights and opportunities. The adoption of this law was a big step for Ukraine on its way to the implementation of European standards and principles of public administration. The law contains many provisions that have been implemented and tested worldwide, in particular, in the European educational legislative practice [18].

However, the question that is difficult to answer is whether the Ukrainian universities are able to be in the innovative business. This question has been studied using SWOT analysis (Fig. 2) based on practical experience of the main university of Ukraine that is Taras Shevchenko National University of Kyiv. According to the Statute and the current legislation, it is a public establishment and it has got a wide range of rights and obligations. All this has been stated in the Law of Ukraine On Education and in the respective orders of the Ministry of Education and Science of
Ukraine [18, 19]. Hence, within the prescribed juridical and financial independence, the University has got a separate balance, separate assets and the right to carry out other activities, in addition to the educational and R\&D ones, which do not contradict the Law. In addition to the status of a pioneer classical higher establishment, the University has obtained additional rights of a separate institution. Its management has got the right of making decisions by themselves through the internal orders, including those concerning the financial and economic issues. They will directly influence the wealth of University's researchers $[18,20]$. By the way, the University has been entitled to the following:

+ to form the structural departments of various types on its basis (science and technological parks, business incubators, small enterprises etc.) combining the interests of hi-tech companies, science, education, business, and the government in order to implement the innovative projects; 
+ to carry out the financial and economic activities according to the Statute of the University:

+ to manage the cash flows, in particular, the proceeds from provision of paid services;

+ to open current and deposit accounts.

In spite of the fact that the University has obtained only the right to participate in the process of creating the innovation structures, in fact, it has also got independence and possibilities to carry out the financial and economic activities, i.e. to gain profits. Therefore, the University cannot be defined as nonprofit establishment any longer.

However, paragraph 1 of Article 27 of the same Law states that higher educational establishment of any type of ownership, including the University, can operate only on the nonprofit basis, which contradicts the law norms mentioned and stated above.

The Scientific Council of the University has the privilege of establishing, restructuring, and liquidating structural departments of the University, including the innovation structures. This action can be accomplished only upon application to the University principal. According to paragraph 3 of Article 27, the University can be a cofounder of various corporate entities that may carry out their activities in the full response to the directions of scientific, educational, productive, and innovative activities of higher education establishment. In addition, paragraph 1 of Article 68, allows the universities to carry out scholarly research, R\&D, and innovative activities as well as to create innovative products and to commercialize them.

Hence, we have now formally declared socially oriented principles of scientific and innovative development (nonprofit ones) based on patriotism and morality and simultaneously start forming the institutional mechanisms for commercial activities of the Ukrainian universities. However, the most interesting innovative projects supported by various foreign funds and organizations are not implemented at the universities. For instance, only 5 of 40 international grants ob- tained in 2016 by researchers and teachers of Taras Shevchenko National University of Kyiv were financed from the Accounting Office of the University [21, 10-18]. The situation was caused by imperfect current legislation and taxation mechanisms for innovative and research activities as well as overregulated knowledge economy.

To regulate the activities in this important segment of the market economy, it is necessary to create the market of scientific and $R \& D$ production as per the Law of Ukraine On Scholarly Research and R\&D Activities (2015, Article 45, paragraphs 8, 9). Also, the need of substantial legislative protection of intellectual property has been pointed out [22].

In fact, the main legislative framework for forming this market is based on the Laws of Ukraine On Investment Activities (1991), On Innovation Activities (2002), and On Science Parks (2009). Thanks to the Law On Science Parks, the pioneer Ukrainian Universities have obtained indirect but legislatively well-grounded possibility to gain profit from selling the $\mathrm{R} \& \mathrm{D}$ results (Article 9, paragraph 2) as well as to combine material efforts and interests of the cofounders. The higher educational establishments of the 4th accreditation level can act as cofounders together with $\mathrm{R} \& \mathrm{D}$ establishments and other corporate entities (Article 1) [23], i.e. private corporations and public organizations.

In the Ukrainian practice, the science parks can be established in the form of limited liability partnership (Science Park of Kyiv National Economic University), corporations (Science Park of Taras Shevchenko National University of Kyiv", "Kyiv Polytechnics Science Park", etc.) or science park (Science Town - Kharkiv science park, Radio Electronics and Informatics science park, etc.) [24].

It is quite possible now to create startups and spinoffs based on universities of Ukraine, research corporations, and scientific parks. However, unfortunately such ideas are being hardly developed.

As for the universities, they are allowed to provide paid services to corporate entities and in- 
dividuals according to Article 73 of the Law of Ukraine and the current statutes.

The scope of these services can be approved by the Cabinet of Ministers of Ukraine and include also scholarly research services, services related to international cooperation, public health protection services, recreation services, sport, culture and other social services in addition to the educational ones [25]. In particular, the universities can provide seminars, workshops, trainings, and consultations. These paid services can be organized by existing structural departments or newly created separate units which may act on the basis of the adopted norms. This means that it is possible to establish some special administrative departments on the basis of university, for instance, a structural department named "startup center" * or "startup school" to organize support of university innovative projects and to hold lectures, trainings, consultations, seminars, and webinars; meetings with successful businessmen, which can be of great interest in the context of explaining the logics of building technological businesses, testing knowledge-intensive business models, and promoting promising business projects. It would be also possible there to find time for consulting with like-minded people and to obtain information about grants, competitions in Ukraine and abroad. The functions of the center can include the formation of students' startup projects, their analysis and prospects.

It is possible (allowed by the legislation [18]) to open a separate university account with a bank in order to separate the activities of the above mentioned department. Now, the main task is to "wake up" interest to innovation and investment activities among the youth as well as to involve them into the innovation entrepreneurship. The level of ready idea can be legally formalized in accordance with paragraph 10 of Article 70, in particular, the formation of mutual statutory

\footnotetext{
* As it has been done in the Samara University [26], the State University of Belarus [27], or federal state higher education establishment "Sankt Petersburg National Research University of Information Technologies, Mechanics, and Optics” [28].
}

capital of newly formed innovation structure with participation of university and a small enterprise that works out and manufactures the goods.

The university that prepares specialists and deals with students from the very beginning of their study can be considered to be the best business incubator for "growing" scholarly researchers, entrepreneurs, and specialists interested in utilizing their own potential in the sphere of innovation. The main conditions in this sphere are a substantial level of preparation in the directions of property rights protection as well as management of innovation business.

To reach this aim the ordinary student should become familiar with innovative business during the first year of education. As a matter of fact, the students should be involved into the process of building innovative business and be motivated for their own business doing from first days of their study. The involvement of students into the innovation business entrepreneurship should be effective but never compulsory. For example, the format of business games helps to understand what business is and to feel as a project maker. The "marketing of innovations" discipline can become a basic one because it teaches both to estimate the ideas from the technological and business point of view and to possess the so called "soft skills", i.e. to present the projects, to convince the potential investors, and to work in team. Even though many projects worked out by students will never be implemented, the students will get knowledge how to estimate prospects of business ideas as well as will be able to understand mechanisms of venture economy. During the last years of education, the students should have their knowledge and skills fixed through studying such courses as "technological entrepreneurship" and "management of innovations" and university programs on business acceleration. They should be able to work at their own projects in order to create their own startups.

As a matter of fact, a successful project for students is the best evidence of practical implementation of knowledge they have got. The graduates 


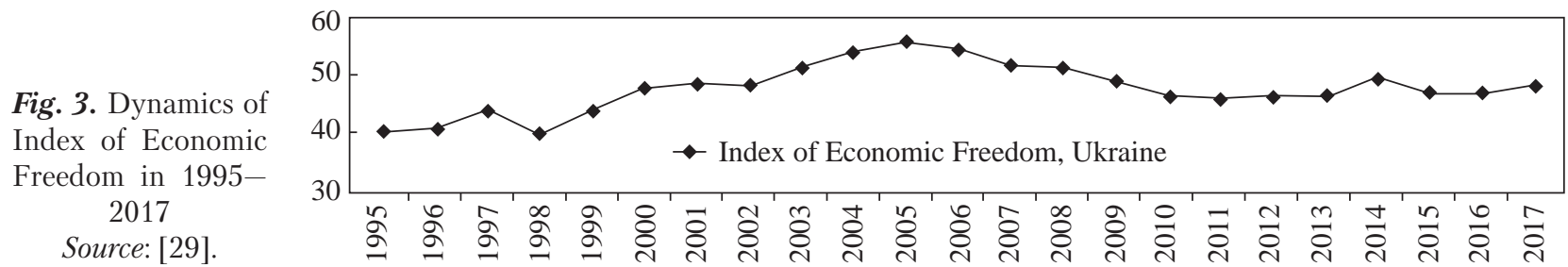

The Economic Position of Ukraine as Compared with Other Countries

Table 2 in the Global World Ratings (as of the end 2017)

\begin{tabular}{|l|c|c|c|c|}
\hline \multicolumn{1}{|c|}{ Countries } & $\begin{array}{c}\text { Index of Economic } \\
\text { Freedom (0-100) / place } \\
\text { in the world rating }\end{array}$ & $\begin{array}{c}\text { Freedom from Corruption } \\
\text { Index }(0-100) / \text { place } \\
\text { in the world rating }\end{array}$ & $\begin{array}{c}\text { Investment Freedom } \\
\text { Index }(0-100) / \text { place } \\
\text { in the world rating }\end{array}$ & $\begin{array}{c}\text { Business Freedom Index } \\
(0-100) * / \text { place } \\
\text { in the world rating }\end{array}$ \\
\hline Hong Kong & $\mathbf{9 0 / 1}$ & $80 / 10$ & $90 / 4$ & $\mathbf{9 5 / 1}$ \\
Singapore & $89 / 2$ & $88 / 4$ & $85 / 15$ & $95 / 2$ \\
New Zealand & $84 / 3$ & $\mathbf{9 0 / 1}$ & $80 / 31$ & $92 / 6$ \\
Switzerland & $82 / 4$ & $87 / 5$ & $85 / 20$ & $91 / 9$ \\
Luxembourg & $76 / 14$ & $78 / 15$ & $\mathbf{9 5 / 1}$ & $69 / 69$ \\
USA & $75 / 17$ & $78 / 16$ & $80 / 33$ & $84 / 19$ \\
Denmark & $75 / 18$ & $85 / 8$ & $90 / 5$ & $94 / 3$ \\
South Korea & $74 / 23$ & $67 / 30$ & $65 / 87$ & $91 / 10$ \\
Finland & $74 / 26$ & $90 / 2$ & $85 / 17$ & $90 / 14$ \\
Germany & $74 / 26$ & $78 / 13$ & $60 / 93$ & $81 / 16$ \\
Malaysia & $74 / 27$ & $52 / 44$ & $75 / 43$ & $70 / 63$ \\
Israel & $70 / 36$ & $48 / 46$ & $75 / 52$ & $68 / 77$ \\
Poland & $68 / 45$ & $56 / 37$ & $70 / 72$ & $82 / 23$ \\
Japan & $70 / 40$ & $86 / 7$ & $20 / 165$ & $54 / 140$ \\
China & $57 / 111$ & $42 / 66$ & $30 / 156$ & $75 / 48$ \\
Russian Federation & $57 / 114$ & $38 / 94$ & $65 / 79$ & $52 / 151$ \\
Lebanon & $53 / 137$ & $23 / 169$ & $\mathbf{2 5 / 1 6 3}$ & $\mathbf{6 2 / 1 1 0}$ \\
Ukraine & $\mathbf{4 8 / 1 6 6}$ & $\mathbf{2 9 / 1 5 3 *}$ &
\end{tabular}

* In 2016, Ukraine was 131 st among 176 world countries by the Corruption Perception Index that is defined by the Transparency International.

Source: [15], [29].

should be able to find promising directions, to work out and to commercialize them as well as to make right decisions during the creation of science-intensive goods.

The promising startup ideas generated while studying or working on theses should be always supported at both commercialization and patent acquisition stages. To have these projects successfully implemented, expensive equipment and working areas are needed. The students should understand how to "pack" their products and who can be their target consumer. All this requires from them time, capital investments, and expertise, i.e. the things which they may not possess. In this case, the university should be able to help and to become a cofounder of small innovative enterprises. This format allows the innovators to get serious privileges, to develop their ideas legally, to promote them to the market, and to gain profits using intellectual property and infrastructure of the university. Such format has proved to be successful in foreign practice. 
Unfortunately, there are many weaknesses in the national system of innovation, which impede the development of innovative activities as whole and at the universities in particular. There have not been created attractive competitive advantages for operation of IT-companies, which makes Ukraine a world outsider in this filed. The initiatives of venture investors who are ready to invest at initial stages of the lifecycle are neglected because of complicated conditions for business doing in Ukraine, legislative and tax uncertainty, corruption and lack of real monopoly right for private property. All this is accompanied with overall financial and political instability.

Because of all these negative factors we can observe the talented youth migration abroad, a reduction in the investments, including the foreign ones, and a great fall in the exports of innovation goods. Recently, the Ukrainian IT-companies have become an object of indictment from police and tax service. That is why at the end of 2016,908 a firm from Dnipro took the entire staff to Poland [29]. Some other companies working in the IT-sphere, in particular, Luxoft (Dnipro), Divan. tv, NIX Solutions, and Intego (Kyiv) have passed through very tough investigations.

Unfortunately, despite having implemented many reforms, year by year, Ukraine is showing downward trend in the world ratings (Diagram 1). Such important indices as Index of Economic Freedom, Freedom from Corruption Index, Investment Freedom, and Business Freedom remain low ([30], Fig. 3 and Table 2). By the way, all of them directly affect the investments and technological innovations. These indices are made up by authoritative American Heritage Foundation and The Wall Street Journal and are considered to be among the most accurate ratings.

Thus, in 2017, Ukraine was ranked by the International Economic Freedom Index among the countries with the lowest economic freedom (the 166th place out of 180, with index 48.1).

In the context of intensification of innovative activities, the startups creation can become a very productive direction because they are the most endurable structures in turbulent institutional conditions of economic activities. In this case, small innovative business is less risky as it "works" in special "hot house" conditions and, consequently, gets protected from outside threats. In addition, the Ukrainian universities possess large material and technological funds as well as intellectual resources, which can reduce sufficiently the required initial investments.

The universities also have advantages when they have startups established and developed on their basis as it stimulates raising the material and technical resources as well as implementing the theoretical knowledge on practice. It also motivates the staff to improve qualification.

However, the Ukrainian universities should continue their work at raising efficiency of management of commercially attractive $\mathrm{R} \& \mathrm{D}$ results as well as at improving their effective transfer to business. To achieve these objectives, it is advisable to make agreements on cooperation with famous American companies dealing with international patenting of university workings and with their commercialization abroad. That means it is necessary to pass the technology transfer to the companies located abroad and having a special expertise in this sphere.

\section{CONCLUSIONS}

Thus, there has not been enough attention paid to strengthening the role of the up-to-date innovative entrepreneurship in the activities of universities in the Ukrainian scholarly research and business environment, in particular, to developing startups and spinoffs. Although we understand the fact that the basic idea of such educational and R\&D projects is the development of science and the implementation of its achievements for the society prosperity we should admit that the commercialization of newly invented workings and results of the innovation activities is crucial for transformation of theoretical knowledge into innovative product with sufficient social and economic value. However, creating the environment for the academic capitalism deve- 
lopment is complicated by rather tough social, economic, and political conditions for starting up the investment projects in Ukraine. A very big obstacle to overcome is the lack of effective institutional management between the science and business. That is why the most important assignment and the priority aspiration of all universities should become implementation of reliable legislative protection of $\mathrm{R} \& \mathrm{D}$ results as well as involvement of technologies transfer mechanisms. The protected results of scientific and innovative research can raise sufficiently the competitiveness of $\mathrm{R} \& \mathrm{D}$ results (inventions and workings). It is a vivid evidence of the priority of such results and defines the culture level of presenting the creative and technical achievements. In addition, it is necessary to make several steps for popularizing the R\&D works on the entrepreneurial basis, strengthening the financial status of universities, etc. It is necessary to do as follows:

+ to work out and to actively promote at the universities methods for motivating researchers and young innovators for creating the intellectual results required by the market and the society;

+ to work at removing the bureaucratic barriers in the creation of protected results of innova- tive activities, which can stimulate the formation of intellectual property market;

+ to focus attention on creating a "disruptive" product or means of solving actual complex tasks, insofar as relevance and innovativeness are the most important criteria to meet the market requirements;

+ to educate the generation of promising young scientists and businessmen interested in research and technological activities as well as in practical implementation of $\mathrm{R} \& \mathrm{D}$ results;

+ to improve the sphere of management of promising $R \& D$ results and their transfer for further use in economic practice, which can become an important image making factor for university.

All these measures enable raising the productivity of innovation activities of these organizations and are a powerful push to a new turn in the economy growth at the national and international levels.

\section{PROSPECTS FOR THE FUTURE SCHOLARLY RESEARCH}

The conclusions formulated will be the basis for searching effective strategies for commercializing the R\&D works of Ukrainian universities.

\section{REFERENCES}

1. Itskovits, G. (2010). Troynaya spiral. Universitetyi - predpriyatiya - gosudarstvo. Innovatsii v deystvii. Tomsk [in Russian].

2. Clark, B. R. (1998). Creating Entrepreneurial Universities: Organizational Pathways of Transformation. London and NewYork.

3. Serbinovskiy, B. Y., Egorova, L. M. (2009). Innovatsionnaya model i integrirovannaya informatsionnaya sreda $v$ upravlenii universitetom novogo tipa. Novocherkassk [in Russian].

4. Röpke, J. (1998). The Entrepreneurial University. Innovation, academicnowledge creation and regional development in a globalized economy. Department of Economics. Germany. September 16. 15 p.

5. Yansen, F. (2002). Epoha innovatsiy. Moskva [in Russian].

6. Zhylinska, O. I. (2016). Rozvytok instytutu patentuvannia v modeli "vidkrytykh innovatsii". Biznes Inform., 12, 12-23 [in Ukrainian].

7. Romanovskyi, O. O. (2012). Fenomen pidpryiemnytstva v universytetakh svitu. Vinnytsia [in Ukrainian].

8. Tatomyr, I. L. (2018). Vplyv akademichnoho kapitalizmu na spin-off aktyvnist dochirnykh kompanii. Finansy Ukrainy: Naukovo-teoretychnyi, informatsiino-praktychnyi zhurnal Ministerstva finansiv Ukrainy. 2 [in Ukrainian].

9. Zbanatskyi, D. (2017). Startapy: yurydychni ta praktychni aspekty. Oznaiomcha chastyna URL: http://n-auditor. com.ua/uk/component/na_archive/155?view=material (Last accessed: 02.04.2018) [in Ukrainian].

10. Why the universityis the ideal startup platform. URL: https://www.wired.com/insights/2014/02/universityideal-startup-platform/(Last accessed: 02.04.2018).

11. Global Entrepreneurship Monitor. URL: http://www.gemconsortium.org/data/key-aps (Last accessed: 02.04.2018).

12. Oxford University leads Europe for $\$ 1$ bn business start-ups. URL: http://www.telegraph.co.uk/education/2017/ 01/30/oxford-university-leads-europe-1bn-business-start-ups/ (Last accessed: 02.04.2018). 
13. Which universities did these unicorn founders go to? URL: https://www.sage.com/en-gb/c/v/unicorn-league/\#founder|founder-universities (Last accessed: 02.04.2018).

14. Startup Europe University Network. URL: http://welcomestartup.eu/startup-europe-university-network/ (Last accessed: 02.04.2018).

15. Universiti Tun Abdul Razak. URL: http://www.unirazak.edu.my/ (Last accessed: 02.04.2018).

16. The Global Innovation Index. URL: https://www.globalinnovationindex.org (Last accessed: 02.04.2018).

17. The Global Economy. URL: http://ru.theglobaleconomy.com (Last accessed: 02.04.2018).

18. Zakon Ukrainy «Pro vyshchu osvitu» vid 01.07.2014 № 1556-VII. URL: http://zakon2.rada.gov.ua/laws/show/ 1556-18 (Last accessed: 02.04.2018) [in Ukrainian].

19. Statut Kyivskoho natsionalnoho universytetu imeni Tarasa Shevchenka, zatverdzhenoho nakazom Ministerstva osvity i nauky Ukrainy vid 24.07.2015 № 802. URL: http://www.prof.univ.kiev.ua/prof/2011-06-14-16-17-19/2011-06-2409-20-58/75-2013-01-16-01-00-41.html (Last accessed: 02.04.2018) [in Ukrainian].

20. Naukovo-doslidnytska robota u Kyivskomu natsionalnomu universyteti imeni Tarasa Shevchenka: pidsumky za 2016 rik i zavdannia na 2017 rik. URL: http://science.univ.kiev.ua/research/report/ZVIT_SCIENCE_2016.pdf (Last accessed: 02.04.2018). [in Ukrainian].

21. Zakon Ukrainy «Pro naukovu i naukovo-tekhnichnu diialnist» vid 26.11.2015 №848-VIII. URL: http://zakon0. rada.gov.ua/laws/show/848-19 (Last accessed: 02.04.2018) [in Ukrainian].

22. Zakon Ukrainy «Pro naukovi parky» vid 25.06.2009 № 1563-VI. URL: http://zakon3.rada.gov.ua/laws/show/156317 (Last accessed: 02.04.2018). [in Ukrainian].

23. Opryshko, D. (2013). Naukovyi park abo korporatsiia «naukovyi park» - pidkhody ta propozytsii. Yurydychna Ukraina, 7, 70-75 [in Ukrainian].

24. Postanova Kabinetu Ministriv Ukrainy «Pro zatverdzhennia pereliku platnykh posluh, yaki mozhut nadavatysia navchalnymy zakladamy, inshymy ustanovamy ta zakladamy systemy osvity, shcho nalezhat do derzhavnoi i komunalnoi formy vlasnosti» vid 27 serpnia 2010 r. № 796. URL: http://zakon2.rada.gov.ua/laws/show/796-2010-\%D0\%BF (Last accessed: 02.04.2018) [in Ukrainian].

25. Samarskiy natsionalnyiy issledovatelskiy universitet imeni akademika S.P. Korolyova. URL: http://www.ssau.ru/ science/ni/pid/startcenter/ (Last accessed: 02.04.2018).

26. Biloruskyi derzhavnyi universytet. URL: http://www.bsu.by/ru/main.aspx?guid=211301 (Last accessed: 02.04.2018) [in Russian].

27. Federalnoe gosudarstvennoe avtonomnoe obrazovatelnoe uchrezhdenie. vyisshego obrazovaniya. «Sankt-Peterburgskiy natsionalnyiy issledovatelskiy universitet. informatsionnyih tehnologiy, mehaniki i optiki» (Universitet ITMO). URL: http://rb.ru/opinion/itmo-i-startapy/ (Last accessed: 02.04.2018) [in Russian].

28. Havryshch, O. Prodaty lytse. Ukrainski IT-startapy stavliat rekordy za sumamy, za yaki yikh kupuiut zakhidni investory. URL: http://nv.ua/ukr/publications/prodati-osoba-ukrajinski-it-startapi-stavljat-rekordi-za-sumami-za-jakijih-kupujut-zahidni-investori-72880.html (Last accessed: 02.04.2018) [in Ukrainian].

29. Index of institute for economic freedom economic freedom (2017). URL: https://www.heritage.org/index/ pdf/2017/book/index_2017.pdf (Last accessed: 02.04.2018).

Received 13.03.18

\author{
I.Е. Новікова ${ }^{1}$, В.Л. Осецький ${ }^{1}$, К.А. Алексеєва ${ }^{2}$ \\ ${ }^{1}$ Київський національний університет імені Тараса Шевченка, \\ вул. Володимирська, 64, Київ, 01601, Україна, \\ +380442393230, ie_novikova@meta.ua \\ ${ }^{2}$ Національний університет біоресурсів і природокористування України, \\ вул. Героїв Оборони, 11, Київ, 03041, Україна \\ +380 44527 8081, katerinaalex@ukr.net

\section{СТАРТ-АПИ ТА СПІН-ОФИ ЯК ФАКТОР РОЗВИТКУ АКАДЕМІЧНОГО БІЗНЕСУ: ЗАРУБІЖНИЙ ДОСВІД ТА УКРАЇНСЬКІ ПЕРСПЕКТИВИ}

Вступ. Сучасні, технологічно-оснащені підприємницькі університети є ідеальним середовищем для формування первинної атмосфери інноваційного бізнес-клімату.

Проблематика. Реалізація сучасних прибуткових інноваційних проектів (старт-апів чи спін-офів) у формі малих інноваційних підприємств є сучасною формою успішної комерціалізації економічно-перспективної ідеї. Досконалим осередком для впровадження першого стартап-замислу є університет. 
Мета. Розгляд тенденцій розвитку академічного бізнесу у контексті посилення значимості інноваційної діяльності, зокрема визначення ролі старт-апів та спін-офів у діяльності зарубіжних та українських університетів.

Матеріали й методи. Використано порівняння рейтингів університетів світу. Застосовано SWOT-аналіз перспективи діяльності старт-ап чи спін-офф проектів на базі університетів в Україні. Проведено аналіз залежності між масштабом витрат на науково-дослідну діяльність та рівнем отриманих результатів інноваційних досягнень.

Результати. Здійснено порівняльний огляд тенденцій розвитку академічного бізнесу закордоном та в Україні. Проаналізовано вітчизняне та європейське законодавство у сфері формування ринку наукової та науково-технічної продукції. Визначено чинники, які суттєво гальмують процес розвитку інноваційної діяльності в Україні. Наведено рекомендації щодо популяризації інноваціно-інвестиційної діяльності та налагодження продуктивної міжнародної співпраці.

Висновки. Одержані результати дозволять сформулювати принципи для формування нової методичної парадигми управління інтелектуальними активами в університетах з урахуванням особливостей розвитку вітчизняної науки, економіки, підприємництва, ринку високих технологій.

Ключові слова: інноваційний бізнес, комерціалізація інновацій, інтелектуальні активи, інтелектуальна власність, старт-ап, спін-оф, університети, академічний капіталізм.

\section{И.Э. Новикова ${ }^{1}$, В.Л. Осеикий ${ }^{1}$, Е.А. Алексеева ${ }^{2}$}

${ }^{1}$ Киевский национальный университет имени Тараса Шевченко, ул. Владимирская, 64, Киев, 01601, Украина, +380 442393230 , ie novikova@meta.ua

${ }^{2}$ Национальний университет биоресурсов и природопользования Украины, ул. Героев Обороны, 11, Киев, 03041, Украина, +380 44527 8081, katerinaalex@ukr.net

\section{СТАРТ-АПЫ И СПИН-ОФФЫ КАК ФАКТОР РАЗВИТИЯ АКАДЕМИЧЕСКОГО БИЗНЕСА: ЗАРУБЕЖНЫЙ ОПЫТ И УКРАИНСКИЕ ПЕРСПЕКТИВЫ}

Введение. Современные, технологически оснащенные предпринимательские университеты являются идеальной средой для формирования первичной атмосферы инновационного бизнес-климата.

Проблематика. Реализация современных прибыльных инновационных проектов (старт-апов или спин-оффов) в форме малых инновационных предприятий является современной формой успешной коммерциализации экономически перспективной идеи. Превосходным центром для внедрения первого стартап-замысла является университет.

Цель. Рассмотрение тенденций развития академического бизнеса в контексте усиления значимости инновационной деятельности, в том числе определение роли старт-апов и спин-оффов в деятельности зарубежных и украинских университетов.

Материалы и методы. Использовано сравнение рейтингов университетов мира. Применен SWOT-анализ перспективы деятельности старт-ап или спин-офф проектов на базе университетов в Украине. Проведен анализ зависимости между масштабом расходов на научно-исследовательскую деятельность и уровнем полученных результатов инновационных достижений.

Результаты. Осуществлен сравнительный обзор тенденций развития академического бизнеса за рубежом и в Украине. Проанализировано отечественное и европейское законодательство в сфере формирования рынка научной и научно-технической продукции. Определены факторы, которые существенно тормозят процесс развития инновационной деятельности в Украине. Приведены рекомендации по популяризации инновационно-инвестиционной деятельности и налаживания продуктивного международного сотрудничества.

Выводы. Полученные результаты позволят сформулировать принципы для формирования новой методической парадигмы управления интеллектуальными активами в университетах с учетом особенностей развития отечественной науки, экономики, предпринимательства, рынка высоких технологий.

Ключевые слова:инновационный бизнес, коммерциализация инноваций, интеллектуальные активы, интеллектуальная собственность, старт-ап, спин-офф, университеты, академический капитализм. 